\title{
Teaching NeuroImages: Trochlear nerve schwannoma
}

Francesca Pastrana, BA, and Sean Gratton, MD

Neurolog ${ }^{\circledR}$ 2020;94:e1448-e1449. doi:10.1212/WNL.0000000000009177

Figure MRI brain with and without gadolinium

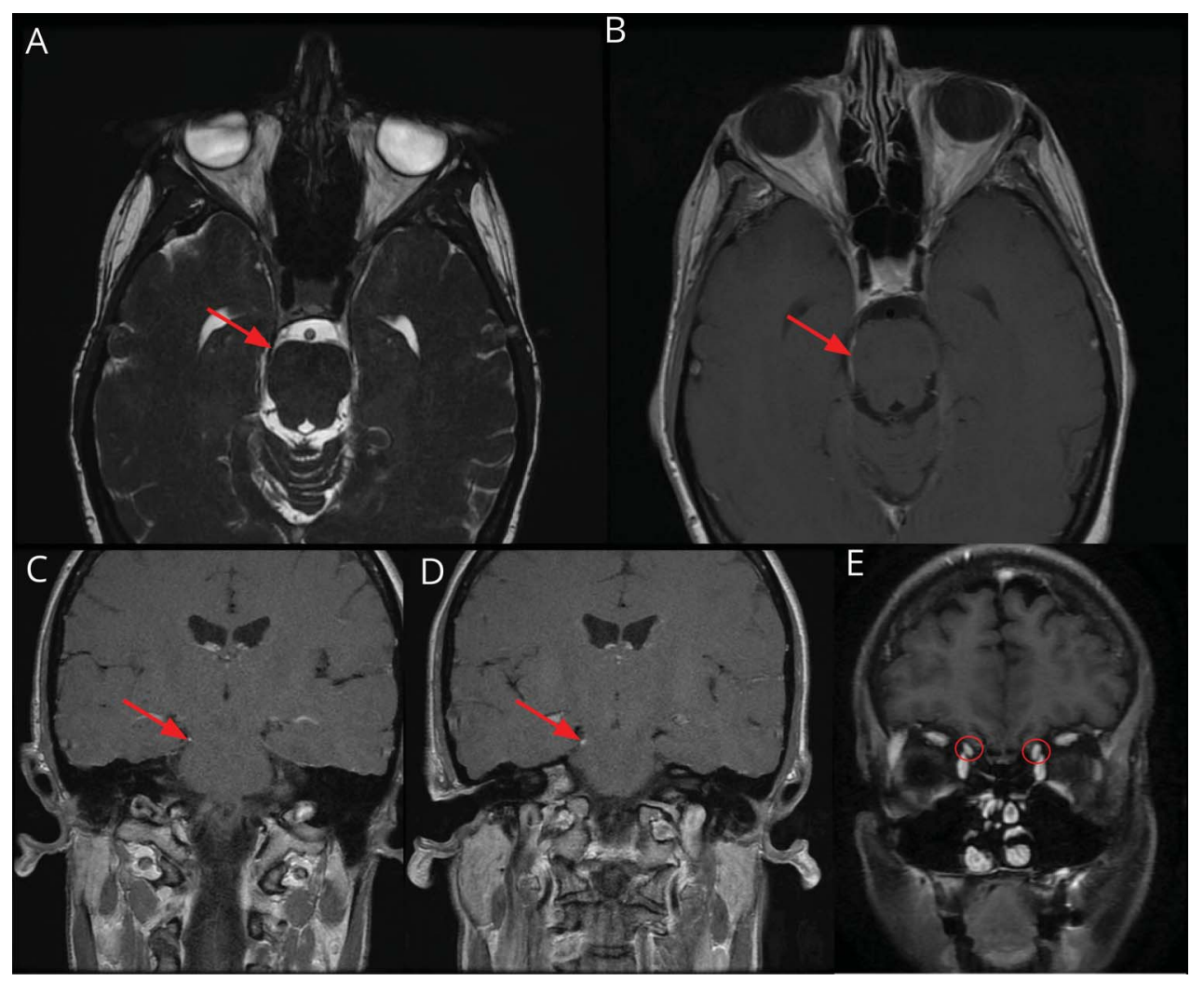

(A) T2 axial image demonstrates thickening of the right trochlear nerve as it passes through the subarachnoid space towards the cavernous sinus. (B) T1 postcontrast axial image shows enhancement of the same segment of nerve. (C, D) T1 postcontrast coronal views of the trochlear nerve enhancement. (E) T1 postcontrast coronal view highlights the superior oblique muscles, with notable atrophy of the right superior oblique.

A 54-year-old woman presented for evaluation of binocular vertical diplopia worse in downgaze. She had limited infraduction of the right eye in adduction and a right hypertropia worse in left gaze and right head tilt, consistent with a right trochlear nerve palsy. MRI brain revealed enlargement and enhancement of the right trochlear nerve in the subarachnoid space (figure). Laboratory testing and CSF analysis were normal. The imaging findings were stable over several years, suggesting the diagnosis of a trochlear nerve schwannoma.

Patients with trochlear nerve schwannomas have a good prognosis. ${ }^{1}$ Serial imaging, observation, and symptomatic treatment with prism spectacles are indicated.

\section{Correspondence \\ Dr. Gratton}

seangratton@gmail.com

\section{MORE ONLINE}

\section{$\rightarrow$ Teaching slides}

links.lww.com/WNL/

B66

From the Departments of Neurology and Ophthalmology (S.G.), University of Missouri-Kansas City School of Medicine (F.P.).

Go to Neurology.org/N for full disclosures. Funding information and disclosures deemed relevant by the authors, if any, are provided at the end of the article. 


\section{Study funding}

No targeted funding reported.

\section{Disclosure}

The authors report no disclosures relevant to the manuscript. Go to Neurology.org/N for full disclosures.

\section{Appendix Authors}

\begin{tabular}{lll}
\hline Name & Location & Contribution \\
\hline $\begin{array}{l}\text { Francesca } \\
\text { Pastrana }\end{array}$ & $\begin{array}{l}\text { University of Missouri-Kansas } \\
\text { City School of Medicine }\end{array}$ & $\begin{array}{l}\text { Drafting and revision } \\
\text { of manuscript }\end{array}$ \\
\hline $\begin{array}{l}\text { Sean } \\
\text { Gratton, }\end{array}$ & University of Missouri-Kansas & $\begin{array}{l}\text { Drafting and revision } \\
\text { for intellectual content }\end{array}$ \\
MD & City School of Medicine &
\end{tabular}

\section{Reference}

1. Elmalem VI, Younge BR, Biousse V, et al. Clinical course and prognosis of trochlear nerve schwannomas. Ophthalmology 2009;116:2011-2016. 


\title{
Neurology
}

\author{
Teaching NeuroImages: Trochlear nerve schwannoma \\ Francesca Pastrana and Sean Gratton \\ Neurology 2020;94;e1448-e1449 Published Online before print February 27, 2020 \\ DOI 10.1212/WNL.0000000000009177
}

This information is current as of February 27, 2020

Updated Information \& Services

References

Subspecialty Collections

Permissions \& Licensing

Reprints including high resolution figures, can be found at: http://n.neurology.org/content/94/13/e1448.full

This article cites 1 articles, 0 of which you can access for free at: http://n.neurology.org/content/94/13/e1448.full\#ref-list-1

This article, along with others on similar topics, appears in the following collection(s):

All Neuro-ophthalmology

http://n.neurology.org/cgi/collection/all_neuroophthalmology Diplopia (double vision)

http://n.neurology.org/cgi/collection/diplopia_double_vision MRI

http://n.neurology.org/cgi/collection/mri

Nerve tumor

http://n.neurology.org/cgi/collection/nerve_tumor

Information about reproducing this article in parts (figures,tables) or in its entirety can be found online at:

http://www.neurology.org/about/about_the_journal\#permissions

Information about ordering reprints can be found online:

http://n.neurology.org/subscribers/advertise

Neurology ${ }^{\circledR}$ is the official journal of the American Academy of Neurology. Published continuously since 1951, it is now a weekly with 48 issues per year. Copyright () 2020 American Academy of Neurology. All rights reserved. Print ISSN: 0028-3878. Online ISSN: 1526-632X.

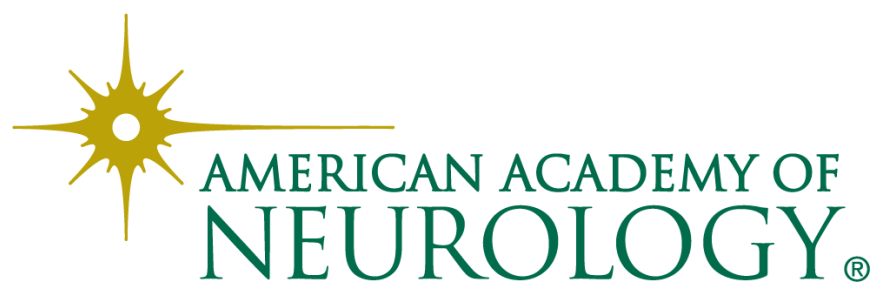

